\title{
Raloxifene and Bazedoxifene Could Be Promising Candidates for Preventing the COVID-19 Related Cytokine Storm, ARDS and Mortality
}

\author{
KAREL SMETANA, JR. ${ }^{1,2}$, DANIEL ROSEL ${ }^{2,3}$ and JAN BRÁBEK ${ }^{2,3}$ \\ ${ }^{1}$ Institute of Anatomy, First Faculty of Medicine, Charles University, Prague, Czech Republic; \\ ${ }^{2}$ BIOCEV, Vestec, Czech Republic; \\ ${ }^{3}$ Department of Cell Biology, Faculty of Sciences, Charles University, Prague, Czech Republic
}

\begin{abstract}
The FDA-approved drugs raloxifene and bazedoxifene could be among the best candidates to prevent mortality in severe COVID-19 patients. Raloxifene and bazedoxifene inhibit IL-6 signaling at therapeutic doses, suggesting they have the potential to prevent the cytokine storm, ARDS and mortality in severe COVID-19 patients, as is being shown with humanized antibodies blocking IL-6 signaling. In addition, raloxifene and bazedoxifene are selective estrogen receptor modulators with strong antiviral activity.
\end{abstract}

In April 2020, we were the first to propose bazedoxifene as one of the most promising candidates to inhibit the IL6/cytokine storm, ARDS and mortality axis in COVID-19 patients with pneumonia $(1,2)$. Bazedoxifene and raloxifene, which belongs to the same class, were developed as estrogen analogs for the treatment of postmenopausal osteoporosis. However, these drugs also interact with GP130, a part of the IL6 receptor $(3,4)$, and prevent the binding of IL6 to its receptor.

Bazedoxifene and raloxifene exhibit anti-inflammatory activity in arthritis (5) and due to their anti-IL6 signaling activity were also found to have anticancer effects, directly associated to their verified potential to inhibit IL6 signaling in animals, at doses similar to therapeutic doses in humans

This article is freely accessible online.

Correspondence to: Jan Brábek, BIOCEV, Průmyslová 595, 25250 Vestec, Czech Republic. Tel: +42 0325873900, e-mail: jan.brabek@natur.cuni.cz; Karel Smetana Jr., Institute of Anatomy, 1st Faculty of Medicine, Charles University, U Nemocnice 3, 128 00 Prague 2, Czech Republic. Tel: +42 0224965873, e-mail: karel.smetana@lf1.cuni.cz

Key Words: SARS-CoV-2, lung failure, cytokine storm, IL6, COVID-19 therapy, bazedoxifene, raloxifene.
(6). Bazedoxifene and raloxifene may therefore represent cheaper and easier alternatives for large scale production, compared to humanized IL6 signaling antibodies for the treatment of severe COVID-19-related lung complications. Moreover, the selective estrogen receptor modulator function of bazedoxifene and raloxifene could be effective against SARS-CoV- 2 entry and replication. Consistently, the in vitro preliminary results indicate that bazedoxifene and raloxifene have strong direct antiviral activity against COVID-19 $(7,8)$.

In addition, raloxifene was identified as a molecule of interest by the Exscalate4CoV consortium, using a unique combination of high-performance computing and AI with biological processing. The consortium virtually tested 400 000 molecules using its supercomputers. 7000 molecules were preselected and further tested in vitro. Raloxifene emerged as a promising molecule; according to the project, it could be effective in blocking the replication of the virus in cells, and could thus hold up the progression of the disease (9), further confirming our proposal.

To conclude, raloxifene and bazedoxifene are among the best candidates to prevent the cytokine storm, ARDS and mortality in severe COVID-19 patients, with the further benefit of a strong antiviral activity.

\section{Conflicts of Interest}

The Authors declare no competing interests.

\section{Authors' Contributions}

K.S., D.R. and J.B. collected data and prepared the article.

\section{References}

1 Smetana K Jr. and Brábek J: Role of interleukin-6 in lung complications in patients with COVID-19: Therapeutic implications. In Vivo 34: 1589-1592, 2020. PMID: 32503815. DOI: 10.21873/invivo.11947 
2 Brábek J, Rosel D, Smetana K and Fernandes M: Repurposing of bazedoxifene to prevent cytokine storm in COVID-19 patients (electronic response to Moore JB and Joone $\mathrm{CH}$ : Cytokine release syndrome in severe COVID-19). Science 368: 473-474, 2020. PMID: 32303591. DOI: 10.1126/science.abb8925

3 Li H, Xiao H, Lin L, Jou D, Kumari V, Lin J and Li C: Drug design targeting protein-protein interactions (PPIs) using multiple ligand simultaneous docking (MLSD) and drug repositioning: discovery of raloxifene and bazedoxifene as novel inhibitors of IL-6/GP130 interface. J Med Chem 57: 632-641, 2014. PMID: 24456369. DOI: $10.1021 / \mathrm{jm} 401144 \mathrm{z}$

4 Ma H, Yan D, Wang Y, Shi W, Liu T, Zhao C, Huo S, Duan J, Tao J, Zhai M, Luo P, Guo J, Tian L, Mageta L, Jou D, Zhang C, Li J, Zhai M, Luo P, Guo J, Tian L, Mageta L, Jou D, Zhang C, Li C, Lin J, Lv J, Li S and Lin L: Bazedoxifene exhibits growth suppressive activity by targeting interleukin6/glycoprotein 130/signal transducer and activator of transcription 3 signaling in hepatocellular carcinoma. Cancer Sci 110: 950-961, 2019. PMID: 30648776. DOI: 10.1111/cas.13940

5 Andersson A, Bernardi AI, Stubelius A, Nurkkala-Karlsson M, Ohlsson C, Carlsten $\mathrm{H}$ and Islander U: Selective oestrogen receptor modulators lasofoxifene and bazedoxifene inhibit joint inflammation and osteoporosis in ovariectomised mice with collagen-induced arthritis. Rheumatology 55: 553-563, 2016. PMID: 26424839. DOI: 10.1093/rheumatology/kev355
6 Thilakasiri P, Huynh J, Poh AR, Tan W, Nero TL, Tran K, Parslow AC, Afshar-Sterle S, Baloyan D, Hannan NJ, Buchert M, Scott AM, Griffin MD, Hollande F, Parker MW, Putoczki TL, Ernst $\mathrm{M}$ and Chand AL: Repurposing the selective estrogen receptor modulator bazedoxifene to suppress gastrointestinal cancer growth. EMBO Mol Med 11: e9539, 2019. PMID: 30885958. DOI: 10.15252/emmm.201809539

7 Jeon S, Ko M, Lee J, Choi I, Byun SY, Park S, Shum D and Kim S: Identification of antiviral drug candidates against SARS-CoV2 from FDA-approved drugs. Antimicrob Agents Chemother 64: e00819-20, 2020. PMID: 32366720. DOI: 10.1128/AAC.00819-20

8 Bakowski M, Beutler N, Chen E, Nguyen TH, Kirkpatrick MG, Parren M, Yang L, Ricketts J, Gupta AK, Hull MV, Schultz PG, Burton DR, Chatterjee AK, McNamara CW and Rogers TF: Oral drug repositioning candidates and synergistic remdesivir combinations for the prophylaxis and treatment of COVID-19. BioRxiv, 2020. DOI: 10.1101/2020.06.16.153403

9 Coronavirus: Using European supercomputing, EU-funded research project announces promising results for potential treatment. Available at: https://ec.europa.eu/commission/presscorner/detail/en/ IP_20_890 [Last accessed on July 1st, 2020]

Received June 27, 2020

Revised June 29, 2020

Accepted July 1, 2020 